\title{
SCREENING CRITERIA FOR MICROBIAL EOR PROCESSES
}

Topical Report

By

Rebecca Smith Bryant

Decernber 1990

Work Performed Under Cooperative Agreement No. DE-FC22-83FE60149

\author{
Prepared for \\ U.S. Department of Energy \\ Assistant Secretary for Fossil Energy
}

\section{Edith Allison, Project Manager}

Bartlesville Project Office

P.O. Box 1398

Bartlesville, OK 74005

Prepared by

IIT Research Institute

National Institute for Petroleum and Energy Research

P.O. Box 2128

Bartlesville, OK 74005

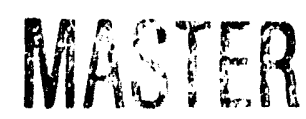




\section{TABLE OF CONTENTS}

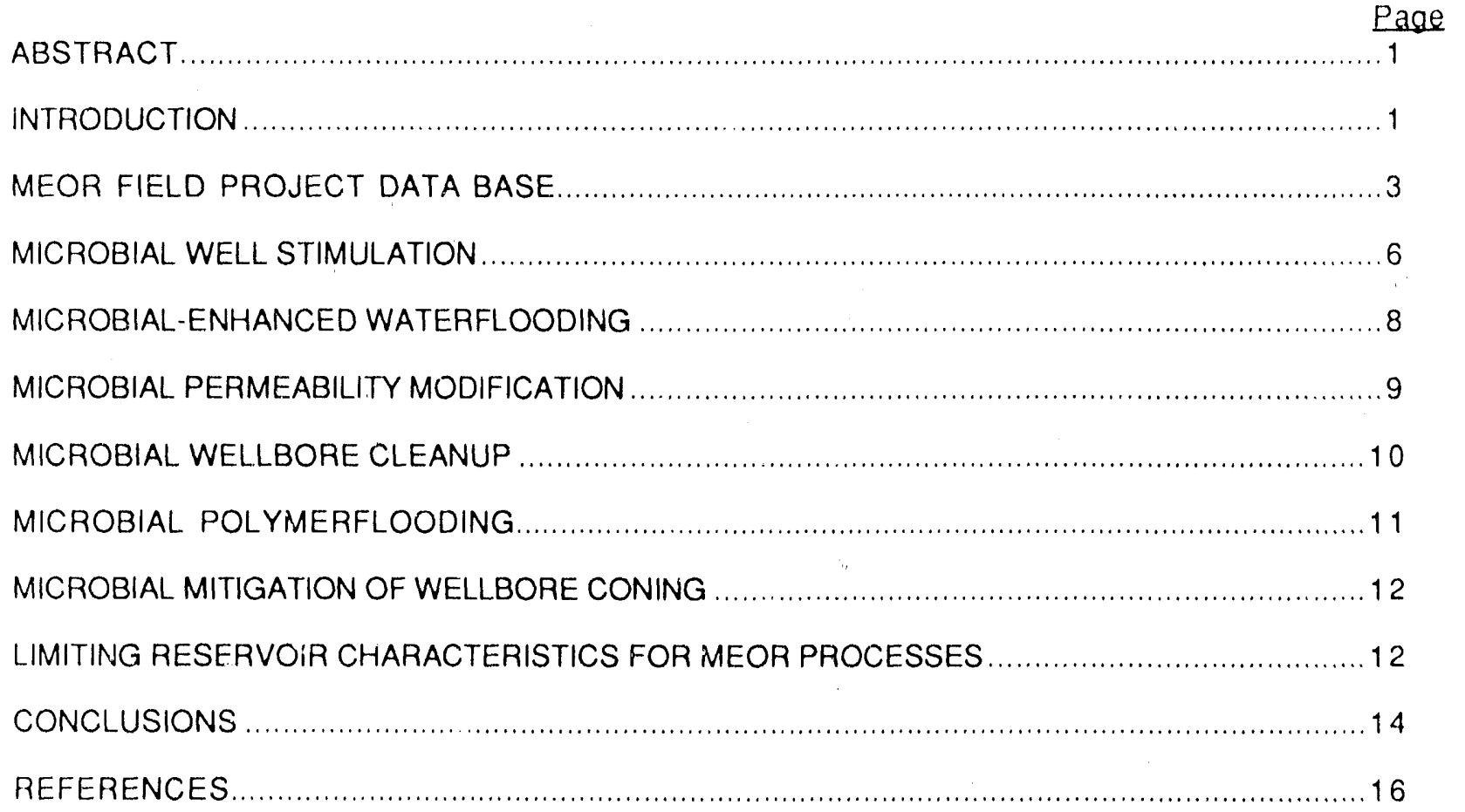

\section{TABLES}

1. Numbar of reservoirs by state with potential for MEOR technology .................................

2. Data elements from NIPER's MEOR Field Project Data Base .......................................... 3

3. A classification of different microbial reservoir treatments........................................6

4. Single-well stimulation tests in the United States and other countries from

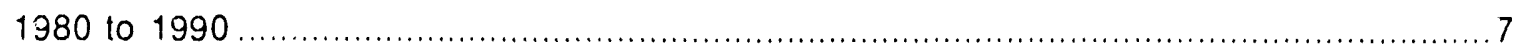

5. Recent microbial-enhanced waterflood field projects.................................................. 9

6. Microbial permeability modification field tests ......................................................... 10

7. Petroleum regions under treatment with Para-BacR products ..................................... 11

8. Reservoir characteristics for single-well stimulation field projects ................................. 13

9. Reservoir characteristics for microbial-enhanced waterlood field projects ......................... 14

10. Screening for MEOR processes in the oikitield ......................................................... 15

11. Revised screening criteria for application of MEOR processes ..................................... 16

\section{FIGURE}

1. Graph showing percent of reservoirs in major oil-producing states that have potential for MEOR processes 


\title{
SCREENING CRITERIA FOR MICROBIAL EOR PROCESSES
}

\author{
Rebecca S. Bryant
}

\begin{abstract}
The National Institute for Petroleum and Energy Research (NIPER) has maintained a microbial enhanced oil recovery (MEOR) field project data base since 1985. One of the major goals of this data base is to continue to document characteristics of reservoirs used for MEOR field projects and to assist the U.S. Department of Energy by revising published screening criteria for MEOR processes. Since the last update of this data base in 1987, the number of MEOR field projects entered has increased from 39 to 65. Microbial EOR has been recognized as a potentially cost-effective method, particularly for stripper well production. Stripper wells are particularly in need of cost-effective EOR because independent operators produce about $40 \%$ of the total oil recovered, but cannot conduct needed EOR research. Microbial methods for improving oil recovery are potentially cost-effective and particularly well suited to be applied in today's economic climate. The lower price of crude oil as well as a more general acceptance of use of biotechnological processes has probably contributed to this increase. Although in some instances information was unavailable or not reported for each element of the data base, there exists adequate data to demonstrate both the viability and variety of options for using microbial technology for improved oil production.
\end{abstract}

This report updates the data base and provides a summary of several of the more important MEOR field experiments conducted during the 1970 s and 1980 s.

\section{INTRODUCTION}

NIPER has maintained a microbial enhanced oil recovery (MEOR) field project data base since 1985. One of the major goals of this data base is to continute to document characteristics of reservoirs used for MEOR field projects and to assist the U. S. Depertment of Energy by revising published screening criteria for MEOR processes.

Several laboratories have published reservoir screenıng criteria, including the University of Oklahoma, ${ }^{1}$ the Baas Becking Geomicrobiological Laboratory in Australia, ${ }^{2}$ and NIPER. ${ }^{3}$ These publications were reviewed to determine which reseivoir parameters are the most imporiant for successful microbial EOR field tests. The U.S. DOE Reservoir Data Base (public copy) was used to screen several oilproducing states for the number of reservoirs that satisfied the following criteria: injectea and connate water salinities less than $100,000 \mathrm{ppm}$, rock permeability greater than 75 millidarcies, and a depth less than 6,800 feet, which corresponds to a temperature limitation of about $75^{\circ} \mathrm{C}$. Table 1 shows the number 
of reservoirs that satisfied these parameters and a graph of the percent of reservoirs in each state that satisfied these limiting criteria, and the total is shown in figura 1.

TABLE 1. Number of reservoirs by state with potential for MEOR technology

\begin{tabular}{lrrr}
\hline State & Total no. of reservoirs & $\begin{array}{l}\text { No. of reservoirs } \\
\text { that fit the criteria }\end{array}$ & $\%$ \\
\hline OK & 97 & 14 & 14 \\
TX & 461 & 115 & 25 \\
LA & 190 & 25 & 13 \\
KS & 39 & 17 & 44 \\
CA & 179 & 85 & 47 \\
CO & 40 & 27 & 68 \\
MS & 44 & 4 & 9 \\
NM & 65 & 3 & 5 \\
WY & 67 & 23 & 34 \\
IL & 46 & 14 & 30 \\
TOTAL & 1228 & 327 & 27 \\
\hline
\end{tabular}

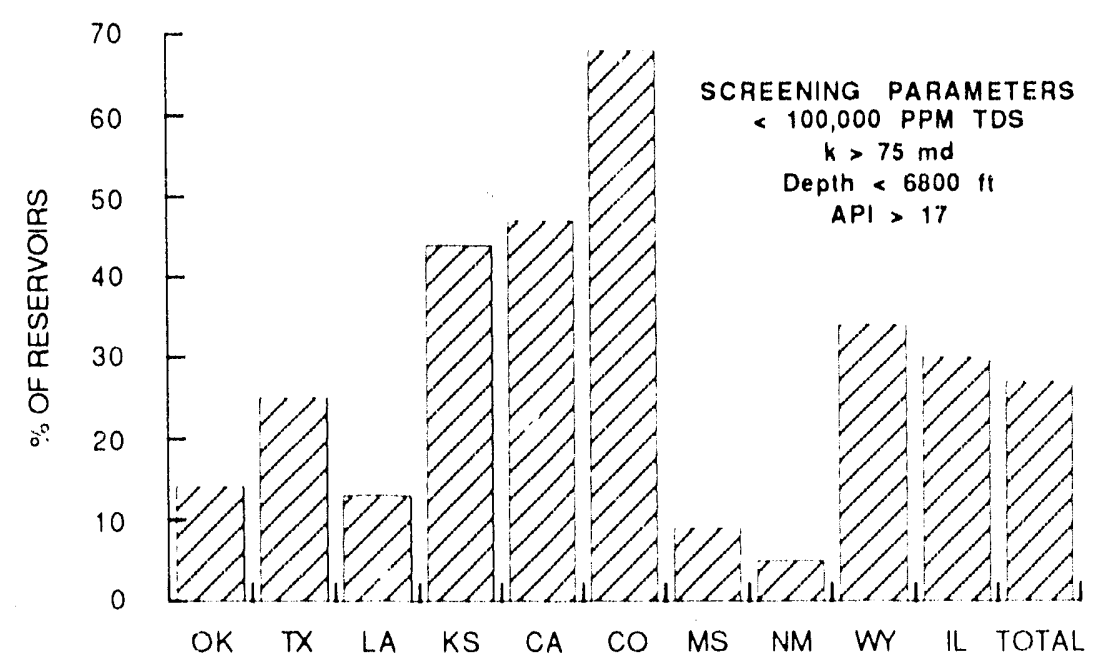

FIGURE 1 -Graph showing percent of reservoirs in major oil-producing states that have potential for MEOR processes. 
Since the most recent publication ${ }^{3}$ of NIPER'S MEOR Field Project Data Base, interest and application in MEOR field technology have increased. Bryant and Burchfield have recently published an overview of MEOR technology. ${ }^{4}$ Because of political changes in Eastern Europe and other countries, some MEOR field trials have now been made public by researchers from countries such as the USSR, Germany, Romania, and China. This report updates the data base ar d provides a summary of several of the more important MEOR field experiments conducted during the 1970s and 1980s.

\section{MEOR FIELD PROJECT DATA BASE}

NIPER has continued 10 maintain a data base on all available information regarding MEOR field tests in the United States and in other countries. The data base was designed to be incorporated into the U.S. Department of Energy's EOR Project Data Base that is part of the Tertiary Oil Recovery Information System (TORIS). The DOE Project Data Base incorporated two new records for MEOR field projects: MEOR Project Info and MEOR Bacteria Info. These two records describe information pertaining to any field project using microorganisms and details the available information regarding the microbial process used. All other data from NIPER's MEOR Field Project Data Base can be incorporated into existing records. A sample data entry sheet is presented in table 2. The MEOR Field Project Data Base was created using Microsoft ${ }^{\mathrm{T} M}$ Excel software for the Macintosh SE personal computer.

TABLE 2. Data elements from NIPER's MEOR Field Project Data Base

\begin{tabular}{ll}
\hline Data element & \multicolumn{1}{c}{ Definition } \\
\hline Reference Number & Nurnber to designate project \\
Organization & Organization conducting project \\
Year of Test & Year project was initiated \\
Oilfield Name & Ex., Delaware-Childers \\
Formation & Ex., Bartlesville Sandstone \\
Permeability, md & Brine permeability of rock, usually an average \\
Porosity, \% & Rock porosity, usually an average \\
Salinity, \% & Usually total dissolved solids value \\
pH & Usually an average \\
Temperature, $" \mathrm{~F}$ & Usually an average \\
Depth, $\mathrm{ft}$ & Bottom of the net pay \\
Pressure, psi & Boltomhole pressure \\
Production Mode & Single pumping wells, or watertlooded \\
\hline
\end{tabular}


TABLE 2. Data elements from NIPER's MEOR Field Project Data Base (continued)

Data element

Definition

Res. Oil Sat., \%

Oil saturation, usually an average

Well spacing, acres

Ex., 5-acre spacing

Net Pay, it

Thickness of pay zone

No. of Inj. Wells

Number of injection wells

No. of Prod. Wells

Number of production wells

Rock Comp.

Type of rock, ex., sandstone

Oil Visc., cP

Viscosity of the crude oil

Oil Gravity, ${ }^{\circ} \mathrm{API}$

API gravity of the crude oil

Oil Density, gm/cc

Density of the crude oil

WOR

Water-oil ratio

Oil Prod., bbl/d

Oil production

Water Prod., bbl/d

Water production

\section{INJECTION INFO}

Preflush

Was a preflush used?

Inj. Fluid Comp.

Composition of injection fluid, ex. microbial

Microbial Type

Name of microorganisms used, ex. Bacillus

Inj. Fluid Visc.

Spores

Viscosity of microbial fluid

Anaerobic

Does the microbe form spores? $Y-N$

Can the microbe grow without oxygen? $\mathrm{Y}-\mathrm{N}$

Pathogen

Is the microbe pathogenic? $Y \cdot N$

$\mathrm{H}_{2} \mathrm{~S}$ Producer

Does microbe produce hydrogen sulfide? $Y-N$

Gases

Does the microbe produce gas?

Acids

Does the microbe produce acids?

Solvents

Does the microbe produce solvents?

Surfactants

Does the microbe produce surfactants?

Polymer

Does the microbe produce polymer?

Nutrient Comp.

What is the nutrient used, ex. molasses?

Inj. Fluid Vol., bblid

Volume of the injected fluid

Inj. Fluid Conc.

Concentration of microbes in the

injection fluid, ex. $1 \times 10^{7}$ cells $/ \mathrm{mL}$

Inj. Nut. Vol., bbl/d

Volume of the injected nutrient 
TABLE 2. Data elements from NIPER's MEOR Field Project Data Base (continued)

Data element

Defirition

Inj. Nutrient Conc.

\section{PILOT INFO}

Test Length, months

Shut-in Period, days

How iong was the project monitored?

Shut-in Pressure

Days that the well(s) was shut-in, if any

Oil Prod., bbl/d

Water Prod., bbl/d

WOR

Oil Viscosity, cP

$\mathrm{pH}$

Pressure that occurred during shut-in

Oil production (afier treatment)

Water production (after treatment)

Water-oil ratio (after treatment)

'iscosity of crude oil after treatment

Comments, \% Inc.

$\mathrm{pH}$ of fluids after treatment

Comments

Several of the parameters listed in table 2 were added specifically because of the nature of microbial enhanced oil recovery processes. These parameters include: injected microorganisms, type of microorganism used; whether they produce spores; their metabolic products, including gases, acids, polymers, solvents, surfactants and hydrogen sulfide; nutrient information; and presence of indigenous microorganisms in the reservoir, flood waters, or nutrients.

Because of the diverse nature of MEOR technology, several different oil production problems have been addressed by microbial and/or nutrient injection. Some classification scheme is required to separate these different processes. To differentiate among field projects using microorganisms, they are separated according to the following classification (table 3) 
TABLE 3 - A classification of different microbial reservoir treatments

\begin{tabular}{lll}
\hline MEOR process & Production problem & Type of microorganism used \\
Microbial well stimulation & $\begin{array}{l}\text { Lack of reservoir pressure } \\
\text { Injectivity problems } \\
\text { Trapped oil due to capillary } \\
\text { forces }\end{array}$ & $\begin{array}{l}\text { Generally surfactant, gas, acid, and } \\
\text { aicohol producers }\end{array}$ \\
Microbial-enhanced waterflooding & $\begin{array}{l}\text { Trapped oil due to capillary } \\
\text { forces }\end{array}$ & $\begin{array}{l}\text { Generally surfactant, gas, acid, and } \\
\text { alcohiol producers }\end{array}$ \\
Microbial permeability modification & $\begin{array}{l}\text { Water bypassing oil } \\
\text { Microbial wellbore cleanup }\end{array}$ & $\begin{array}{l}\text { Microorganisms that produce polymer } \\
\text { and/or copious amounts of biomass }\end{array}$ \\
& $\begin{array}{l}\text { Paraffin problems } \\
\text { Scaling }\end{array}$ & $\begin{array}{l}\text { Microorganisms that produce } \\
\text { emulsifiers, surfactants, and acids }\end{array}$ \\
Microbial polymerflooding & $\begin{array}{l}\text { Microorganisms that degrade } \\
\text { hydrocarbons }\end{array}$ \\
Mitigation of coning & Wnfavorable mobility ratio & Microorganisms that produce polymer \\
Water bypassing oil & $\begin{array}{l}\text { Microc ganisms that produce polymer } \\
\text { and/or copious amounts of biomass }\end{array}$ \\
\hline
\end{tabular}

The processes listed in table 3 will be used for classification only; in some instances, no field projects using the process are being conducted, but field work has been planned based upon laboratory results.

\section{MICROBIAL WELL STIMULATION}

The most practiced MEOR technique involves cyclic treatments of producing wells. These types of treatments have been conducted since 1953; however, those conducted most recently have involved some im proved nutrient and microbial processes. These tosts are addressed in this report.

In well stimulation treatments, improvements in oil production can result from removal of paraffinic or asphaitic deposits from the near-wellbore region or from mobilization of residual oil in the limited volume of the reservoir that is treated. Because there is a potential for improved residual oil mobilization, these treatments are distinguished from those that use microorganisms specifically for wellbore cleanup. Well stimulation treatments generally use microorganisms that require the addition of nutrient to survive and thrive for periods of several months in the well, whereas microorganisms used for wellbore cleanup are those that generally do not survive for extended periods of time and are injected on a regular basis, 
somewhat similar to regular injection of hot oil. They generally do not survive outside the wellbore region without nutrient injection because they are oxygen-requiring microbes. Typically well stimulation treatments can be implemented with only a few minor modifications to existing surface facilities, and they are relatively inexpensive.

Well stimulation treatments can be considered successful not only by improving oil production rate but also by decreasing the cost of maintenance and operation of a well. As an example, a microbial formulation that reduces BS\&W (bottom sediments and water) can improve injectivity of a well and decrease the life of the well. By improving injectivity, maintenance treatments of a well, such as hot oil or solvent treatments, may not have to be implemented as often.

During the 1950s and 1960s, countries such as Czechoslovakia, Poland, Hungary, and the USSR conducted numerous well stimulation treatments with a wide variety of microorganisms and injection protocols. Underlying trends in all of these early single-winll injections are that they used inexpensive sources of nutrients (usually molasses), and that they were generally successful, i.e., had increases in oil production rate ranging from 50 to $300 \%$.

In the 1970s and 1980s, researchers at some universities and small companies in the United States conducted probably as many as 300 well stimulation treatments. Unfortunately, the information resulting from all but a few of these is unavailable to the public. Those for which information is available are presented in table 4 .

TABLE 4 - Well stimulation tests in the United States and other countries from 1980 to 1990

\begin{tabular}{|c|c|c|c|}
\hline Project conducted by & Year of test & Field/State & Reported results ${ }^{1}$ \\
\hline Oklahoma State University & 1983 & Oklahoma & Oil production increased \\
\hline Oklahoma State University & 1985 & Texas & Slight increase in oil production \\
\hline Microbial Systems Corp. & 1984 & Oklahoma & $\begin{array}{l}230 \% \text { increase in oil broduction } \\
\text { rate for } 7 \text { months }(0.0, \cup 2 \mathrm{bbl} / \text { day })\end{array}$ \\
\hline Fairleigh Dickinson Lab. & 1986 & $\begin{array}{l}\text { Gailjo field } \\
\text { Texas }\end{array}$ & Operator left \\
\hline Fairleigh Dickinson Lab. & 1987 & $\begin{array}{l}\text { Wildcat field } \\
\text { Texas }\end{array}$ & Slight increase in oil production \\
\hline Petroleum Bioresources, Inc. & $1983-84$ & $\begin{array}{l}\text { Westfork field } \\
\text { Colorado }\end{array}$ & $\begin{array}{l}\text { Rapid increase in oil production } \\
\text { rate with rapid decline after } 5 \\
\text { months }\end{array}$ \\
\hline Alpha Environmental, Inc. & 1986 & $\begin{array}{l}\text { Lavernia field } \\
\text { Texas }\end{array}$ & $\begin{array}{l}\text { Slight increase in cil production } \\
\text { rate in off-pattern leases }\end{array}$ \\
\hline
\end{tabular}


TABLE 4. Well stimulation tests in the United States and other countries from 1980 to 1990 (continued)

\begin{tabular}{llll}
\hline Project conducted by & Year of test & Field/State & Reported results $^{1}$ \\
\hline Alpha Environmental, Inc. & $1986-87$ & $\begin{array}{l}\text { Longwood field } \\
\text { Texas }\end{array}$ & BS\&W2 decreased \\
BWN Oil (Australia) & $1988-89$ & $\begin{array}{l}\text { Alton field, } \\
\text { Australia }\end{array}$ & $\begin{array}{l}\text { Oil production increased and } \\
\text { BS\&W } W^{2} \text { decreased }\end{array}$ \\
\hline
\end{tabular}

${ }^{1}$ See references 5 and 6.

2 Bottom sediments and water.

\section{MICROBIAL-ENHANCED WATERFLOODING}

For a microbial-enhanced waterflood, it is important that the microorganisms be capable of moving through the reservoir and producing chemical products to mobilize crude oil. Microorganisms can produce surfactants that can reduce oil/water interfacial tension (IFT) and cause emulsification. In addition, surfactants can alter the relative permeability of rock to oil by changing the wettability of the reservoir rock and thereby increasing oil recovery. Microbes also produce gases such as $\mathrm{CO}_{2}, \mathrm{~N}_{2}, \mathrm{H}_{2}$, and $\mathrm{CH}_{4}$ that could improve oil recovery by increasing reservoir pressure and by reducing the viscosity and swelling of individually trapped droplets of crude oil. Sometimes, particularly with heavy crude oils, production of $\mathrm{CO}_{2}$ may decrease the viscosity of the oil enough to lead to some improvement in oil production. In carbonate formations or sandstone rocks with carbonaceous cementation, acid-producing microorganisms can increase permeability and thereby improve oil recovery.

Microorganisms that are most commonly used for MEOR field processes are species of Bacillus and Clostridium. These species have a greater potential for survival in petroleum reservoirs because they produce spores. Spores are dormant, resistant forms of the cells that can survive more stressful environmental conditions. Clostridium species produce surfactants, gases, alcohols and solvents, while Bacillus species produce surfactants, acids, and some gases. Thert are also Bacillus species that produce polymers.

More care must be taken to ensure that the microorganisms can transport in a waterflood rather than in single-well stimulation treatments. However, the potential for a much greater increase in oll production is high because of the larger amount of reservoir contacted or treated. One of the first successful MEOR field pilots occurred in 1954, and consisted of an injection well and a production well. ${ }^{7}$ More recent microbial-enhanced waterllood projects have been conclucted by the National Institute for Petroleum and Energy Research (NIPER), ${ }^{8-9}$ Imperial Energy Corporation, Alpha Environmental, as well as by countries such as Romania, East Germany, and the USSR (table 5). 
Many of these microbial waterfloods showed increases in oil production rate. The MEOR process responsible for the improved production is generally attributed to gas and surfactant production by the microorganisms.

TABLE 5 - Recent microbial-enhanced waterflood field projects

\begin{tabular}{|c|c|c|c|}
\hline Project conducted by: & Year of test & Field/State & Reported results 1 \\
\hline $\begin{array}{c}\text { NIPER/Microbial Systems Corp. } \\
\text { and INJECTECH, Inc. }\end{array}$ & 1986 & $\begin{array}{l}\text { Delaware/Childers field } \\
\text { Oklahoma }\end{array}$ & $\begin{array}{l}\text { Oil pruduction increased and } \\
\text { water/oil ratio decreased }\end{array}$ \\
\hline $\begin{array}{l}\text { NIPER/Microbial Systems Corp. } \\
\text { and INJECTECH, Inc. }\end{array}$ & 1990 & $\begin{array}{l}\text { Chelsea-Alluwe field } \\
\text { Oklahoma }\end{array}$ & Injected in June, 1990 \\
\hline Imperial Energy Corp. & 1988 & Loco field, Oklahoma & Oil viscosity decreased \\
\hline Alpha Environmental, Inc. & 1988 & $\begin{array}{l}\text { Longwood field } \\
\text { Illinois }\end{array}$ & Oil production increased \\
\hline Romania Test 1 & 1987 & Romania & Oil production increased \\
\hline Romania Test 2 & 1987 & Romania & Oil production increased \\
\hline Romania Test 3 & 1987 & Romaria & Oil viscosity decreased \\
\hline Romania Test 4 & 1987 & Romania & Oil viscosity decreased \\
\hline East Germany & 1987 & East Germany & $\begin{array}{l}\text { Oil production increased and } \\
\text { vater/oil ratio decreased }\end{array}$ \\
\hline USSR & 1987 & $\begin{array}{l}\text { Bondyuzhskoe } \\
\text { USSR }\end{array}$ & $\begin{array}{l}\text { Significant oil production } \\
\text { increase }\end{array}$ \\
\hline
\end{tabular}

1 See references $5-10$.

\section{MICROBIAL PERMEABILITY MODIFICATION}

Another application for microorganisms in a waterflood is fluid diversion. Since many types of microorganisms produce polymers, it has been suggested that some microorganisms could be used in situ to plug high-permeability zones in reservoirs preferentially and thus improve sweep efficiency. ${ }^{11}$ in 1958, researchers in The Netherlands conducted a selectivn plugging experiment using Betacoccus dextranicus and reported significant increases in oil production as well as an improved water/oil ratio. Microorganisms that produce polymers, biomass, and slimes have been shown to reduce core permeability under reservoir conditions in the laboratory. More recent field tests are reported in table 6. The University of Oklahoma is currently planning a field test for its fluid diversion MEOR process. ${ }^{12}$ 
TABLE 6 - Microbial permeability modification fleld tests

\begin{tabular}{|c|c|c|c|}
\hline Projeci conducted by & Year of test & Fieid/Stale & Reported results ${ }^{1}$ \\
\hline University of Oklahoma & 1990 & $\begin{array}{l}\text { SE Vasser Vertz Sand } \\
\text { Oklahoma }\end{array}$ & Planned \\
\hline Nova Husky Research Corp. & 1988 & $\begin{array}{l}\text { Lloydminister } \\
\text { Canada }\end{array}$ & $\begin{array}{l}\text { Results appeared promising } \\
\text { although permeability } \\
\text { channels not obsiructed }\end{array}$ \\
\hline USSR. & 1989 & $\begin{array}{l}\text { Romashkinskoye } \\
\text { USSR }\end{array}$ & Additional oil recovered \\
\hline
\end{tabular}

1 See references $5,11-13$.

\section{MICROBIAL WELLBORE CLEANUP}

Use of microorganisms in the near-wellbore region can greatly improve injectivity and mitigate certain production problems. Several different companies promote microbial wellbore cleanup technology; however, information from most of these production operations is usually proprietary. One microbial treatment company, Micro-Bac International, provided a listing of petroleum regions where its microbial products are in use and several case histories of microbial wellbore cleanup. ${ }^{14}$ That company has estimated that 2,500 to 3,000 wells have been treated using its microbial products, and this number does not include production tank or barge treatments for boitom sediments and water (BS\&W) or paraffin. Oil production increases have occurred in about $50 \%$ of all wells treated, with increases in total fluid produced ranging from 100 to $10 \%$. Table 7 lists petroleum-producing regions treated with the product from MicroBac International, Para-Bac ${ }^{\circledR}$. From the available information, it is clear that in certain instances, microbial injection in the near-wellbore region can rival certair tixisting chemical treatmenis, both in efficiency and cost. 15 
TABLE 7.- Petroleum regions under treatment with ParaBac $^{\circledR}$ products

\begin{tabular}{ll}
\hline Reģion & State \\
\hline & \\
Anadarko Basin & OK \\
Appalachian Basin & PA,KY \\
Arkoma Basin & AR \\
Austin Chalk & TX \\
Dalhart Basin & TX \\
Gulf Coast Salt Dome Basin & LA \\
Hugoton Embayment & KS,OK \\
Illinois Basin & IL \\
LaSalle Uplift & IL \\
Michigan Basin & MI \\
Midland Basin & TX \\
Palo Duro Basin & TX \\
Powder River Basin & WY \\
Sabine Uplift & LA \\
San Luis Basin & CO \\
Sweetgrass Arch & MT \\
Tyler Basin & TX \\
Turumcari Basin & NM \\
Unita BasinUplift & MT \\
Williston Basin & \\
\hline All regions are in the United States; data Current as oí \\
August, 1990. & \\
\hline &
\end{tabular}

\section{MICROBIAL POLYMERFLOODING}

Few data have been published regarding MEOR processes where the amount of injected microorganisms that produce polymer is activaliy equivalent to that of a conventional polymerlood. Moses $^{16}$ has conducted laboratory research in this area, but no field test results have been published. Researchers in China recently reported on laboratory tests involving novel microorganisms that produce polymer which they intend to field test sometime later in $1990 .{ }^{17}$ 


\section{MICROBIAL MITIGATION OF WELLBORE CONING}

Researchers at the University of Calgary have patented a methodology for using ultramicrobacteria to plug the area around the production well and thus alleviate water coning problems. ${ }^{18}$ No fiald trials have been reported to the public.

\section{LIMITIAG RESERVOIR CHARACTERISTICS FOR MEOR PROCFSSES}

Microbial enhariced sil recovery fieh, projects have been conducted under a wide range of reservoir conditions (tables 8 and 9 ). Well stimulation microbial treatments have been done in wells with connate brine salinities greater than $11 \%$. Microbial-enhanced waterllooding projects have been conducted in waters with a total dissolved solids (TDS) concentration value as high as $32 \%$. Although in the high salinity case, it is piobably not entirely sodium chloride that is responsible for the high value. In the past. most reservoir screening criteria used a TDS limit of $10 \%$, or $100,000 \mathrm{ppm}$. Obviously, there are microorganisms that can grow at much higher TDS values, and the East German microbial-enhanced waterlood demonstrates this point. ${ }^{10}$ As a revised screening criterion, it is recommended that the sodium concentration continue to be less than $10 \%$ although the TDS value may be much higher. The presence of high (5 to $10 \mathrm{ppm}$ ) concentrations of some metals such as arsenic, nickel, and selenium will affect microbial growth, and fluid compatibility sludies and a reservoir brine analysis can be used to ide ntify any potential problems with metal ions. Some researchers claim that carbonate rock is desirable for microbial EOR processes. Since many microbes produce acids when fermenting molasses, it is believed that the presence of carbonate minerals can improve microbial $\mathrm{CO}_{2}$ production. as well as increase permeability. ${ }^{10}$

Reservoir rock. permeability ranges of one to thousands of millidarcies (md) have been reported for MEOR tield projects. In some instances, for example in well sumula' 'ion treatments, the permeability factor is probably less critical since the primary objective is to improve oil recovery in the near-wellbore region. The crucial lactor for single-well treatments should be good injectivity. In microbial-enhanced waterflooding, reservoir rock permeability becomes a more important consideration. However, successfu! field tests have been demonstrated in rock that was previously conside: ed too tight for microbial treatment i< 100 md; 8.9 A single $w \in l l$ injectivity test can provide valuable information to thuse producers considering microbial-enhanced waterlooding. If injectivity is unaffected after microbial injection, then permeability may not be a limiting factor for that particular reservoir. In revised screening criteria, therefore. no limitations will be placed on permeability, although it is recommended that a single well injectivity test be conducted prior to a multiwell microbial waterfiood. It is also recommended that if a particular formation is known to have low permeability, then microbial EOR may not be a viable process 
No MEOR field projects have been reported where the pressures and temperatures were too high for microbial growth. The usual biological limitation for temperature is about $158^{\circ} \mathrm{F}\left(70^{\circ} \mathrm{C}\right)$, and the pressure limitation is about $20,000 \mathrm{psi}$. The testing of microbial compatibility with reservoir fluids under reservoir conditions is recommended prior to any microbial field test, even well stimulation treatments. The temperature constraints for microbial growth occur with individual microbial species and therefore will not be considered under revised screening criteria. The presence of indigenous microorganisms, as cited in previous screening criteria, is still a major concern. The microorganisms used for crude oil mobilization must survive and thrive in the reservoir. Compatibility testing using the indigenous microorganisms of that particular reservoir is also highly recommended. In those reservoirs with more haish environmental characteristics for microbial survival, the possibility of stimulating indigenc'ss microorganisms is feasible.

Although most MEOR field projects have been conducted with light crude oils having API gravities around $30^{\circ} 1040^{\circ}$, successes have been reporiad with heavy crudes having gravities around $20^{\circ}$ API. Obviously the higher the viscosity of a crude oil, th, more difficult it will be to mobilize; yet, the principal mechanisms of microorganisms for improved displicement efficiency, gas, surfactant and solvent production, and wettability alteration should still apply.

TABLE 8 - Reservoir characteristics for single-well stimulation field projects

\begin{tabular}{|c|c|c|c|c|}
\hline Project conducted by & TDS, \% & Permeability, md & Depth, $\mathrm{ft}$ & Oil gravity, ${ }^{\circ} \mathrm{API}$ \\
\hline Oklahoma State University & 3.0 & $\left({ }^{1}\right)$ & 1,750 & $\left({ }^{1}\right)$ \\
\hline Oklahoma State University & 4.6 & $(1)$ & 450 & 36 \\
\hline Microbial Systems Corp. & 11.0 & 26 & 700 & 34 \\
\hline Fairleigh Dickinson Lab. & $(1)$ & $(1)$ & 2,550 & 40 \\
\hline Fairleigh Dickinson Lab. & 0.8 & $\left({ }^{1}\right)$ & 350 & 20 \\
\hline Petroleum Bioresources, Inc. & (1) & $\left({ }^{1}\right)$ & 5,200 & (1) \\
\hline Alpha Environmental, Inc. & 1.0 & 43 & 1,500 & 32 \\
\hline Alpha Environmental, Inc. & 4.0 & 25 & 2,120 & 39 \\
\hline BWN Oil Co. (Australia) & (1) & 260 & $\left({ }^{1}\right)$ & Medium-light \\
\hline
\end{tabular}

Tenotes value unavailable or not reported. 
TABLF 9 - Reservoir characteristics for microbial-onhianced waterflood field projects

\begin{tabular}{|c|c|c|c|c|c|c|c|}
\hline Project conducted by & TDS, \% & $\begin{array}{c}1 \text { Perm, } \\
\text { md }\end{array}$ & Depth, & $\begin{array}{l}\text { Oil Gravity, } \\
{ }^{\circ} \mathrm{API}\end{array}$ & $\begin{array}{l}\operatorname{Visc}^{2} \\
\mathrm{cP}\end{array}$ & $\begin{array}{l}\text { Temp., } \\
{ }^{\circ} \mathrm{F}\end{array}$ & $\begin{array}{l}\text { Rock } \\
\text { type }\end{array}$ \\
\hline $\begin{array}{l}\text { NIPER/Microbial Systems } \\
\text { and INJECTECH, Inc. }\end{array}$ & 0.02 & 92 & 650 & 34 & 7.0 & 77 & SS \\
\hline $\begin{array}{l}\text { NIPER/Microbial Systems } \\
\text { and INJECTECH, Inc. }\end{array}$ & 2.6 & 31 & 450 & 31 & 8.2 & 75 & SS \\
\hline Imperial Energy Corp. & 3.8 & (3) & (3) & 21 & $(3)$ & (3) & SS \\
\hline Alpha Environmental, Inc. & (3) & $5-165$ & 2,620 & 37 & (3) & 80 & SS \\
\hline Romania - Test 1 & 0.5 & 245 & 2,461 & $(3)$ & 16 & 117 & SS \\
\hline Romania - Test 2 & 0.45 & $100-1,000$ & 2,560 & (3) & 26 & 97 & SS \\
\hline Romania - Test 3 & 0.5 & $100-500$ & 2,297 & (3) & 46 & 113 & LS \\
\hline Romania - Test 4 & 0.9 & $400-1,300$ & 3,937 & $(3)$ & 33 & 124 & SS \\
\hline East Germany & 32.0 & $10-50$ & 4,068 & 30.6 & (3) & 150 & LS \\
\hline USSR & 0.02 & 500 & 5.577 & (3) & (3) & 90 & SS \\
\hline
\end{tabular}

\section{CONCLUSIONS}

The increasing number of microbial enhanced oil recovery field projects and the variety of different microbial processes that are applicable demonstrates the difficulty and complexity of placing reservoir limitations on the technology. Rather, it is recommended to the national laboratories, universities, small companies, and foreign governments conducting these projects that emphasis should be placed upon the adequate design of a particular field project prior to its implementation. Some thought must be given to what type of microbial process is desired, which means that first some knowledge of the reservoir problern nust be obtained. Knowledge of the reservoir problem must be determined before a microbial solution to that problen van be designed. Simple compatibility studies between reservoir fluids and microorganisms can be adequate in many cases to predict whether microorganisms can be applied successfully. Compatibility tests are usually test tube experiments in which several microbial formulations are grown in the presence of reservoir fluids and sometimes reservoir rock. Measurements of the growth 
and inetabolite production of the microorganisms and comparisons are made. Essentially, a revision of screening criteria for MEOR processes in the oilfield becomes a matter of selection of particular microbial formulations for specific reservoir conditions after the problem is defined. The most important reservoir criteria to be considered are listed in table 10.

TABLE 10 - Recommendations for screening procedures for application of MEOR processes in the oilfield

\begin{tabular}{ll}
\hline Parameter & Screening procedure \\
\hline Microorganism used & $\begin{array}{l}\text { Determine potential mechanisms for increasing } \\
\text { oil production }\end{array}$ \\
Salinity & $\begin{array}{l}\text { Use compatibility testing to assay for } \\
\text { microbial growth and metabolism }\end{array}$ \\
Temperature/depth & $\begin{array}{l}\text { Use compatibility testing to assay for } \\
\text { microbial growth and metabolism under } \\
\text { reservoir conditions }\end{array}$ \\
Reservoir rock permeability & $\begin{array}{l}\text { Use compatibility testing to determine deleterious } \\
\text { effects on microbial growth and metabolism }\end{array}$ \\
Indigenous microorganisms & $\begin{array}{l}\text { If multiwell process, conduct a single-well } \\
\text { injectivity test and coreflooding studies }\end{array}$ \\
Use compatibility testing to assay for \\
microbial growth and metabolism under \\
reservoir conditions
\end{tabular}

The nature of the reservoir to be used for MEOR technology will severely affect the success of the process. If the reservoir is highly channeled, injecting a microorganism that produces only a surfactant may not recover a significant amount of oll since the microorganisms will continue to remain in the water phase and thus bypass much of the trapped crude. By contrast, if there is no channeling and the reservoir permeability is low, injecting a microorganism that produces only a polymer and biomass may decrease injectivity and cause undesirable plugging. Sometimes the mineral content of the connate water may inhibit the growth of the selected microorganisms. If that happens, it may be possible to stimulate microorganisms that are indigenous to the water so that they can act to mobilize crude oil. Researchers at the University of Oklahoma found that they were required to try this approach when the salinity of the brine was much higher than their microorganisms could tolerate. ${ }^{9}$ In the USSR, scientists are conducting microbial EOR field trials by stimulating indigenous microorganisms with injection of aerated and carbonated water. ${ }^{19}$ A revised list of screening criteria is presented in table 11. 
TABLE 11 Revised screening criteria for application of MEOR processes in the oilfield

\begin{tabular}{ll}
\hline Parameter & Recommended range \\
\hline Salinity & $<10 \%$ sodium chloride; total TDS may be higher \\
Temperature/depth & $<170^{\circ} \mathrm{F} ;<8,000 \mathrm{H}$ \\
Trace minerals & $<10-15 \mathrm{ppm}$ of arsenic, mercury, nickel, selenium \\
Reservoir rock permeability & $>50$ millidarcies, unless highly fractured \\
Indigenous microorganisms & $\begin{array}{l}\text { Compatible with injected microorganisms in } \\
\text { selected MEOR process }\end{array}$ \\
Crude oil type & $>15 \circ \mathrm{API}$ not enough information available yet for \\
heavier crude oils & $>25 \% ;$ may be some exceptions \\
Residual oil saturation & $<40$ acres; a response can generally be seen \\
Well spacing & sooner on closer well spacing
\end{tabular}

Clearly, there are many options available to oil producers interested in microbial enhanced oil recovery. Because of the nature of micrnbial growth and the ability of microorganisms to utilize relatively inexpensive chemicals as nutrients, the economics should be attractive under almost any circumstance. No one microbial process will be a panacea, nor be successful in every reservoir; yet, the fact that there are so many options remains the exciting and challenging facet of MEOR technology.

\section{REFERENCES}

1. Clark, J.B. , D.M. Munnecke, and G.E. Jenneman. In situ Microbial Enhancement of Oil Production, Chapter 63 in Developments in Industrial Microbjology, 1981, pp. 695-701.

2. Bubela, B. and B.A. McKay. Assessment of Oll Reservoirs for Microbiological Enhanced Oil Recovery. Microbes and Oll Recovery, v. 1, International Bioresources Journal, 1985, pp. 99-107.

3. Bryant, R.S. MEOR Data Base and Evaluation of Reservolr Characteristics for MEOR Projects. U.S. Dept. of Energy Report No. NIPER-272, August, 1989. NTIS order No. DE89000764.

4. Bryant, R.S., and T.E. Burchfleld. Review of Microbial Enhanced Oil Recovery Technology. SPE Reservoir Engineering, May, 1989, SPE Paper No. 16646. 
5. Hitzman, D.O. Review of Microbial Enhanced Oil Recovery Field Tests. Proc. Symposium on Applications of Microorganisms to Petroleum Technology, U.S. Dept. of Energy Report No. NIPER351, September, 1988. NTIS order No. DE88001232.

6. Oppenheimer, C.H. and F.K. Hiebert. Microbiological Techniques for Paraffin Reduction in Producing Oil Wells. U. S. Dept. of Energy Report No. DOE/BC/14014-9, April, 1989.

7. Yarbrough, H.F. and V.F. Coty. Microbially Enhanced OIl Recovery from the Upper Cretaceous Nacatoch Formation, Union County, Arkansas. Proc. International Conf. on Microbial Enhanced Oil Recovery, Afton, OK, May 16-21, 1982, Dept. of Energy Report No. Conf-8205140,1982, pp. 149 153.

8. Bryant, R.S., Burchfield, T.E., Dennis, M.D., and Hitzman,D.O. Microbial. Enhanced Waterflooding: Mink Unit Project. SPE Reservoir Engineering, February, 1990, SPE Paper No. 17341.

9. Bryant, R.S., Burchfield, T.E., Dennis, M.D., Hitzman, D.O. and Porter, R.E. "Microbial-Enhanced Waterllooding: A Pilot Study". Pres. at the International Conierence on Microbial Enhancement of Oil Recovery, Norman, OK, May 27-31, 1990.

10. Wagner, O. Microbial Enhancement of Oil Recovery From Carbonate Reservoirs With Complex Formation Characteristics. Pres. at the International Conference on Microbial Enhancement of Oil Recovery, Norman, OK, May 27-31, 1990.

11. Jack, T.R., B.G.Thompson, and E. DiBlasio. The Potential for Use of Microbes in the Production of Heavy Oil. Proc., International Conf. on Microbial Enhanced Oil Recovery, Afton, OK, May 16-21, 1982, Dept. of Energy Report No. Conf-8205140, 1982, pp. 88-93.

12. Knapp, R.M., M.J. Mclnerney, D.E. Menzie, and R.A. Raiders. Microbial Field Pilot Study. U.S. Dept of Energy Report No. DOE/BC/14084-6. January, 1989.

13. Jack, T.R. Field and Laboratory Results for a Bacterial Selective Plugging System, Pres. at the International Conterence on Microbial Enhancement of Oil Recovery, Norman, OK, May 27-31, 1990.

14. Schneider, Dennis R., Micro-Bac International, Inc., personal communication, August 20, 1990.

15. Pelgar, J. MEOR Research on Wellbore Stimulation, Pres, at the International Conference on Microbial Enhancement of Oil Recovery, Norman, OK, May 27-31, 1990.

16. Moses, V., personal communication, April, 1989

17. Wang, X-Y.Studies of the Thermally Generated Gel-agent Produced by PS. aeruginosa for EOR, Pres. at the International Conference on Microbial Enhancement of Oil Recovery, Norman, OK, May 27-31, 1990.

18. Costerton, J.W.F., F. Cusack, and F.A. MacLeod. Microbial Process for Selectively Plugging a Subterranean Formation. U.S. Patent No. 4,800,959, Jan. 31, 1989.

19. Ivanov, M.V.Biotechnology of Enhancement of Oil Recovery, Based on the Geochemi: al Activity of Microorganism Field Experiments, Pres. at the International Conference on Microbial Enhancernent of Oil Recovery, Norman, OK, May 27-31, 1990. 

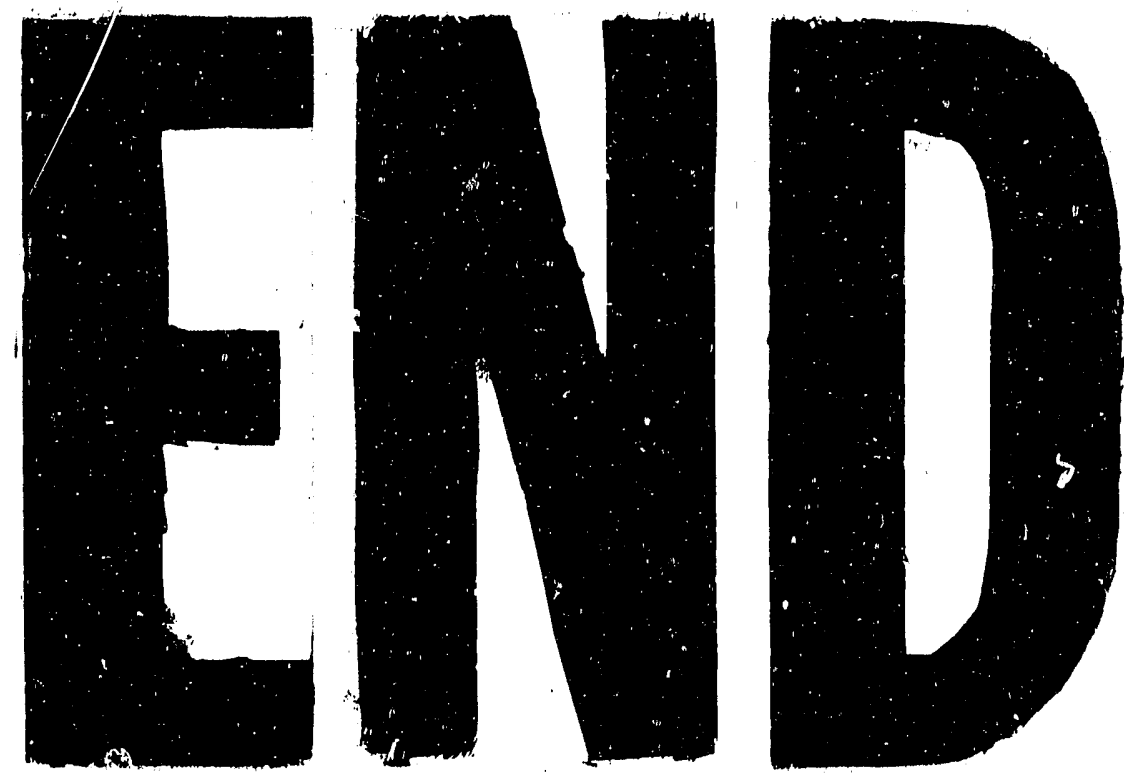

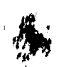
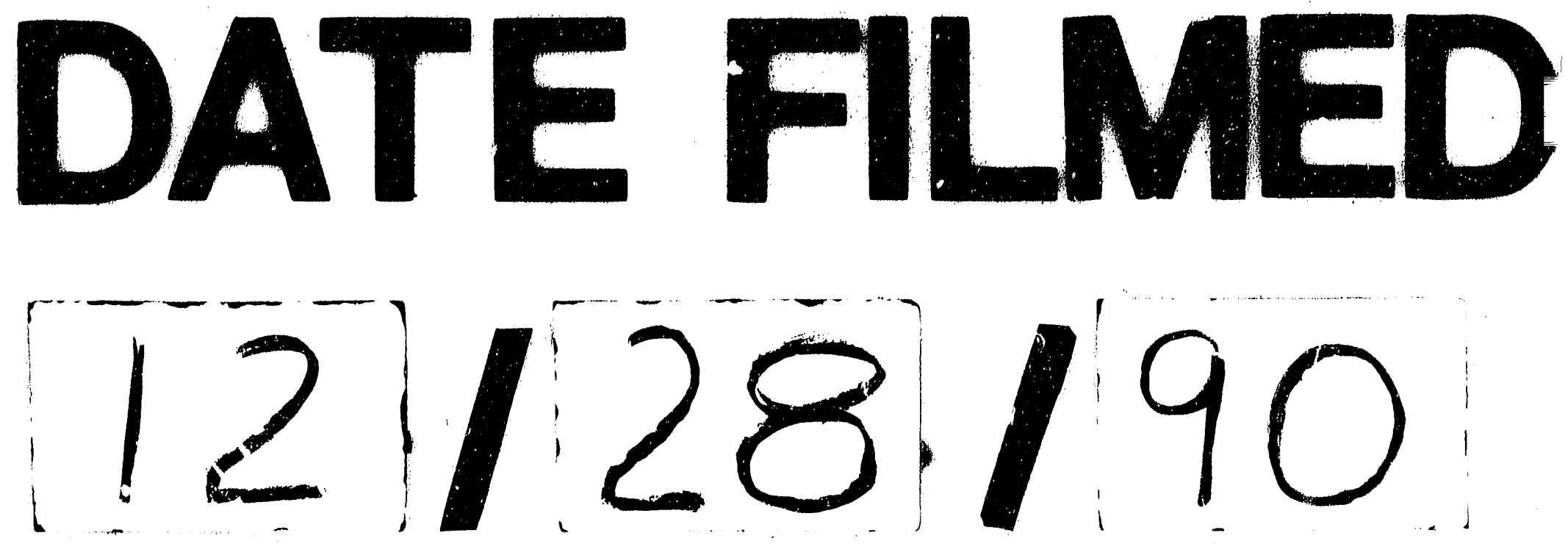
